Foundation; Health and Safety Executive; Department of Health; National Heart Lung and Blood Institute (RO1HL36310), US, NIH; National Institute on Aging (RO1AG13196), US, NIH; Agency for Health Care Policy Research (RO1-HS06516); and the John D and Catherine T MacArthur Foundation Research Networks on Successful Midlife Development and Socioeconomic Status and Health. PM is also supported by the Academy of Finland (grant 48600) and the Signe and Ane Gyllenberg Foundation. MJS is supported by the British Heart Foundation. MGM is a Medical Research Council research professor. GDS was a Wellcome Fellow in Clinical Epidemiology when baseline data for this study were collected. Competing interests: None declared.

1 Ferrie J, Shipley MJ, Marmot MG, Stansfeld S, Davey Smith G. Health effects of anticipation of job change and non-employment: longitudinal data from the Whitehall II study. BMJ 1995;311:1264-9.

2 Ferrie J, Shipley M, Marmot MG, Stansfeld S, Davey Smith G. An uncertain future. The health effects of threats to employment security in whitecollar men and women. Am J Public Health 1998;88:1030-6.

3 Draper P. The rise and demise of the PSA. Government Purchasing 1995;May:8-9.

4 Marmot MG, Davey Smith G, Stansfeld S, Patel C, North F, Head J, et al. Health inequalities among British civil servants: the Whitehall II study. Lancet 1991:337:1387-93.

5 Goldberg DP. Manual of the general health questionnaire. Windsor: National Foundation for Education Research Publishing, 1979.

6 Bradburn NM. The structure of psychological wellbeing. Chicago: Aldine, 1969.

7 Pearlin LI, Schooler C. The structure of coping. J Health Soc Behav 1978;19:2-21.

8 Karasek R. Job demands, job decision latitude, and mental strain: implications for job redesign. Admin Sci Q 1979;24:285-311.

9 Cobb S, Kasl SV. Termination. The consequences of job loss. Cincinatti National Institutes for Occupational Safety and Health, 1977 (DHEW-NIOSH Publication No 77-224)

10 Iversen L, Sabroe S. Psychological well-being among unemployed and employed people after a company closedown: a longitudinal study. J Soc Issues 1988;44:141-52.

11 Dew MA, Bromet EJ, Penkower L. Mental health effects of job loss in women. Psychol Med 1992:22:751-64.

12 Hamilton V, Hoffman W, Broman CL, Rauma D. Unemployment, distress, and coping: a panel study of autoworkers. J Pers Soc Psychol 1993;65:234 47.

13 Burchell B. The effects of labour market position, job insecurity, and unemployment on psychological health. In: Gallie D, Marsh C, Vogler C, eds. Social change and the experience of unemployment. Oxford: Oxford University Press, 1994:188-212.

14 Leana CR, Feldman DC. Finding new jobs after a plant closing: antecedents and outcomes of the occurrence and quality of reemployment Human Relations 1995;48:1381-401.

15 Murphy GC, Athanasou JA. The effect of unemployment on mental health.J Occup Organ Psychol 1999;72:83-9.

16 Bjorklund A, Eriksson T. Unemployment and mental health: evidence from research in the Nordic countries. Scand J Soc Welfare 1998;7:219-35.

17 Beale N, Nethercott S. Job-loss and family morbidity: a study of a factory closure. J R Coll Gen Pract 1985;35:510-14.

18 Rowlands P, Huws R. Psychological effects of colliery closure. Int J Soc Psychiatry 1995;41:21-5.

19 Yuen P, Balarajan R. Unemployment and patterns of consultation with the general practitioner. BMJ 1989;298:1212-4.

20 Mathers CD, Schofield DJ. The health consequences of unemployment: the evidence. Med J Aust 1998;168:178-82.

21 D'Arcy C, Siddique CM. Unemployment and health: an analysis of “Canada Health" data. Int J Health Serv 1985;15:609-35.

22 Carr-Hill RA, Rice N, Roland M. Socioeconomic determinants of rates of consultation in general practice based on fourth national morbidity survey of general practices. BMJ 1996;312:1008-12.

23 Kivimaki M, Vahtera J, Pentti J, Ferrie JE. Factors underlying the effect of organisational downsizing on the health of employees: a longitudinal cohort study of changes in work, social relationships and health behaviours. BMJ 2000;320:971-5.

24 Barling J, Kelloway EK. Job insecurity and health: the moderating role of workplace control. Stress Med 1996;12:253-9.

25 Rodgers B. Socio-economic status, employment and neurosis. So Psychiatry Psychiatr Epidemiol 1992;26:104-14.

26 Jackson PR, Warr P. Unemployment and psychological ill-health: the moderating role of duration and age. Psychol Med 1984;14:605-14.

27 Whelan C. The role of income, life-style deprivation and financial strain in mediating the impact of unemployment on psychological distress: evidence from the Republic of Ireland. J Occup Organ Psychol 1992;65:331-44.

28 Macleod J, Davey Smith G, Heslop P, Oliver S, Hart C. Always look on the bright side of life? The influence of reporting tendency when exposure and outcome measurements are based on self report. J Epidemiol Commu nity Health 1999;53:660

29 Janlert U. Work deprivation and health:consequences of job loss and unemployment. Lulea, Sweden: Karolinska Institute, 1991.

30 Arjas-Leino P, Liira J, Mutanen P, Malmivaara A, Matikainen E. Predictor and consequences of unemployment among construction workers: prospective cohort study. BMJ 1999;319:600-5.

(Accepted 16 January 2001)

\title{
Cardiovascular events in users of sildenafil: results from first phase of prescription event monitoring in England
}

\author{
Saad A W Shakir, Lynda V Wilton, Andrew Boshier, Deborah Layton, Emma Heeley
}

Sildenafil is used to treat erectile dysfunction, and prescription on the NHS is restricted. We are conducting a study of prescription event monitoring for sildenafil in England, the first phase of which investigates possible short term effects in a cohort of about 5000 users. In view of the interest in myocardial infarction as a possible short term side effect $^{1}$ we report on an analysis of selected cardiovascular events reported in the first phase.

\section{Methods and results}

Prescription event monitoring has been described elsewhere. ${ }^{2}$ Patients were identified from NHS prescriptions in England. Simple questionnaires were posted to the prescribing general practitioners about five months after the first prescription. These forms requested reporting of events after the drug had been prescribed. An "event" was any new diagnosis, any reason for referral to a consultant or admission to hospital, unexpected deterioration (or improvement) in a concurrent illness, suspected drug reaction, clinically important alterations in laboratory measurements or other investigations, or any other complaint considered to be of sufficient importance to enter in the patient's notes.

We sent questionnaires for 9748 patients who were first prescribed sildenafil between September 1998 and March 1999. Of the 5950 questionnaires returned, 5601 contained usable information. The mean (SD) age of the patients was 57.4 (11.3) years (range 18-90 years). The main indication for use of sildenafil was impotence $(3552 ; 63.4 \%)$; the indication was not specified in 1927 (34.4\%). Diabetes mellitus was the second indication in $789(14.1 \%)$, and in $39(0.7 \%)$ it was the primary indication. Eighty three patients had other first indications for treatment. The number of patients with diabetes may be an underestimate as data on more than one indication for treatment are not specifically requested. Three months after the first prescription $85.6 \%$ were still using the drug.

We followed up all patients with non-fatal myocardial infarction and selected patients with angina,
Drug Safety Research Unit, Bursledon Hall, Southampton SO31 1AA

Saad A W Shakir director Lynda V Wilton senior research fellow Andrew Boshier clinical research fellow Deborah Layton research pharmacist Emma Heeley research fellow

Correspondence to: S A W Shakir saad.shakir@dsru.org

BMJ 2001;322:651-2 
Standardised mortality calculation for ischaemic heart disease/myocardial infarction. Figures are numbers for cohort unless stated otherwise

\begin{tabular}{lcccccc} 
Age (years) & $\begin{array}{c}\text { No of } \\
\text { patients }\end{array}$ & $\begin{array}{c}\text { Years of } \\
\text { observation }\end{array}$ & $\begin{array}{c}\text { No of } \\
\text { deaths }\end{array}$ & $\begin{array}{c}\text { No of } \\
\text { deaths/year }\end{array}$ & $\begin{array}{c}\text { Deaths/1000/ } \\
\text { year in England } \\
\text { (1998) }\end{array}$ & $\begin{array}{c}\text { Expected No of } \\
\text { deaths in } \\
\text { cohort/year }\end{array}$ \\
\hline $15-24$ & 15 & 0.55 & 0 & 0 & 0.003600 & 0.000054 \\
\hline $25-34$ & 145 & 0.51 & 0 & 0 & 0.028400 & 0.004118 \\
\hline $35-44$ & 473 & 0.49 & 0 & 0 & 0.222000 & 0.105006 \\
\hline $45-54$ & 1171 & 0.51 & 1.00 & 1.97 & 0.978100 & 1.145355 \\
\hline $55-64$ & 1583 & 0.50 & 5.00 & 10.00 & 3.277600 & 5.188440 \\
\hline $65-74$ & 1200 & 0.50 & 2.00 & 4.01 & 9.153800 & 10.984560 \\
\hline$\geqslant 75$ & 190 & 0.48 & 2.00 & 4.21 & 60.278400 & 11.452896 \\
\hline Not specified & 824 & 0.49 & $\mathrm{~N} / \mathrm{A}$ & $\mathrm{N} / \mathrm{A}$ & $\mathrm{N} / \mathrm{A}$ & $\mathrm{N} / \mathrm{A}$ \\
\hline Total & 5601 & 0.50 & 10.00 & 20.20 & 73.941900 & 28.88 \\
\hline
\end{tabular}

ischaemic heart disease, and chest pain. In patients who were taking sildenafil non-fatal events were angina (nine), chest pain (19), ischaemic heart disease (five), and myocardial infarction (seven) and fatal events were myocardial infarction (six) and ischaemic heart disease (four). One death was certified as congestive cardiac failure/ischaemic heart disease after intercourse. Four of the 10 patients who died were known to have had diabetes.

We used indirect standardisation to compare mortality from ischaemic heart disease (ICD-9 (international classification of diseases, 9th revision) codes 410-414) in the cohort with that in the general population of England in 1998 (table). ${ }^{3}$ The standardised mortality ratio of 69.9 (95\% confidence interval 42.7 to 108.0, based on Poisson error factors) indicates that the mortality in the cohort is $30.1 \%$ lower than that for English men in 1998, after adjustment for confounding effects of age.

\section{Comment}

The standardised mortality ratio indicates no evidence for a higher incidence of fatal myocardial infarction or ischaemic heart disease among men taking sildenafil. Underreporting of adverse events is possible, and bias caused by non-response among general practitioners and NHS restrictions on prescribing sildenafil cannot be excluded. The prevalence of diabetes in the cohort was $15 \%$, which is similar to that $(16 \%)$ in the manufacturer's clinical trials ${ }^{4}$ but much higher than that in the general population (3.3\% in men in England in 1998). ${ }^{5}$ Though our results are reassuring it is inappropriate to accept these comparisons as definitive evidence of equivalence between this cohort of sildenafil users and men in the general population in England. This hypothesis needs to be examined by further clinical and pharmacoepidemiological research.

Contributors: The research was conceived by SAWS, who also monitored study progress, wrote the paper, and discussed the analysis. LVW verified the data and analysis and wrote the paper. $\mathrm{AB}$ coordinated the analysis and wrote the paper. DL gave advice on statistical analysis. EH analysed the data and wrote the paper. SAWS is guarantor.

Competing interests: Drs Shakir and Wilton have received financial support from Pfizer to attend conferences overseas.

Funding: The Drug Safety Research Unit is a registered charity (No 327206). It receives unconditional grants from several pharmaceutical companies. These companies have no say in the conduct of the studies and have no statistical or editorial control over analysis or reporting of results.

1 Arora RR, Timoney M, Melilli L. Acute myocardial infarction after use of sildenafil. N Engl J Med 1999;341:700.

2 Mann RD. Prescription-event monitoring-recent progress and future horizons. Br J Clin Pharmacol 1998;46:195-201.

3 Office for National Statistics. Mortality statistics: general. Review of the registrar general on deaths in England and Wales, 1998. London: Stationery Office, 2000.

4 Pfizer. Viagra. Summary of product characteristics. New York: Pfizer, 1998 (revised September 2000).

5 Bajekal M, Boerham R, Erens B, Falaschetti E, Hirani V, Primatesta P, et al. Health Survey for England: cardiovascular disease '98. A survey carried out on behalf of the Department of Health. London: Stationery Office, 1999.

(Accepted 26 February 2001)
Editorial by Sørensen and Echwald

Pennington Biomedical Research Center, Louisiana State University, Baton Rouge, LA 70808, USA

Roland Rosmond postdoctoral

researcher

Claude Bouchard executive director

continued over

BMJ 2001;322:652-3
Chronically elevated cortisol levels can increase body fat, as seen clearly in Cushing's syndrome. Subjects with abdominal obesity share many of the hormonal, metabolic, and circulatory characteristics of people with Cushing's syndrome. A dysfunctional glucocorticoid receptor may add to the adverse health effects of excessive cortisol concentrations.

An Asn363Ser polymorphism in exon 2 of the glucocorticoid receptor gene (GRL) might be associated with overweight and an increased sensitivity to exogenous glucocorticoids. ${ }^{1}$ We therefore examined whether this variant was associated with altered sensitivity to glucocorticoids as well as obesity with its related metabolic and haemodynamic abnormalities in a cohort of Swedish men. ${ }^{2}$

\section{Participants, methods, and results}

Subjects (a total of 284 men) were randomly selected from a larger cohort of men born in Gothenburg, Sweden, in 1944. The design of the study has been described elsewhere. ${ }^{3}$ Measurements reported here were carried out in Gothenburg during 1995. All men gave written informed consent before participating in the study, which was approved by the local ethics committee.

Anthropometric measurements included body mass index, waist to hip ratio, and abdominal sagittal diameter. Salivary cortisol was measured repeatedly during an ordinary working day that had been selected at random. In addition, an overnight low dose $(0.5 \mathrm{mg})$ 